\title{
Introduction success of less common species from the genus Berberis $L$.
}

\author{
Y. V. Lykholat ${ }^{1}$, N. O. Khromykh ${ }^{1}$, T. Y. Lykholat ${ }^{1}$, O. M. Bobrova ${ }^{1}$, O. O. Didur ${ }^{1}$, O. A. \\ Lykholat $^{2}$, V. M. Sudak ${ }^{3}$, T. V. Legostaeva ${ }^{1}$, Z. V. Gtytzaj ${ }^{1}$, A. M. Kabar ${ }^{1}$, V. M. Savosko ${ }^{4}$, \\ I. M. Kovalenko ${ }^{5}$, V. R. Davydov ${ }^{1}$, K. M. Suvorova ${ }^{4}$, K. A. Dudkina ${ }^{1}$, O. M. Kolinko ${ }^{1}$, I. P. \\ Grygoryuk $^{6}$
}

\author{
${ }^{1}$ Oles Honchar Dnipro National University, Gagarin av., 72, Dnipro, Ukraine, 49010 \\ ${ }^{2}$ University of Customs and Finance, Volodymyr Vernadsky St. 2/4, Dnipro, Ukraine, 49000 \\ ${ }^{3}$ Government Agency Institute of Grain Crops, Vernadsky Str., 14, Dnipro, Ukraine, 49000 \\ ${ }^{4}$ Kryvyi Rih State Pedagogical University, Gagarin av., 54, Kryvyi Rih, Ukraine, 50000 \\ ${ }^{5}$ Sumy' National Agricultural University, Kondratyeva Str., 160/5, Sumy, 40021 \\ ${ }^{6}$ National University of Life and Environmental Sciences of Ukraine, Geroiv Oborony Str., 13, Kyiv, Ukraine, \\ 03041 \\ E-mail: didur@ua.fm
}

Received 25.10.2019 Accepted 13.12.2019

\begin{abstract}
The study dealt with the patterns of adaptation of the genus Berberis L. low-abundant alien plants to the climatic conditions of the steppe zone of Ukraine. The success of the introduction, which was conducted on the territory of the Botanical Garden of Oles Honchar Dnipro National University (city of Dnipro) near 60 years ago, was evaluated by a set of indicators. According to the study of phenological rhythms, introduced plants can be characterized as plants with a relatively short growing season, a relatively long shoot growth, a short flowering period and a long maturing period. This indicates the lability of the phenological rhythms of the introduced plants, which respond to changes in environmental conditions in terms of the beginning and end of the phenological phases. The aquatic regime of introduced plants reflects the level of their adaptation to the environment due to the ability of plant organism to withstand water consumption. The study of water exchange features of Berberis $L$. plants revealed a moderate decrease in the intensity of transpiration and a moderate water deficit in the plant leaves, which indicates the adaptation of the species to the difficult climatic conditions of the steppe zone. The response of introduced plants to the level of moisture in the steppe region confirmed the universal mechanism of plant adaptation to arid conditions. Comparative analysis of the reproductive ability of introduced plants of the genus Berberis $L$. in the conditions of the Botanical Garden revealed a significant variability of quantitative indicators. The weight of 100 fruits ranged from $12.5 \mathrm{~g}$ (B. vulgaris) to $16.3 \mathrm{~g} \mathrm{(B.} \mathrm{declinata).} \mathrm{Seed} \mathrm{length} \mathrm{varied} \mathrm{from}$ $4.5 \mathrm{~mm}$ (B. canadensis) to $5.2 \mathrm{~mm}$ (B. declinata, B. amurensis), seed width varied from $1.8 \mathrm{~mm}$ (B. amurensis, B. vulgaris) to 2.1 $\mathrm{mm}$ (B. koreana). The highest mass of 1000 seeds was observed in the species B. koreana. To compare sample averages, the criterion for the significant difference of Tukey's group averages was used. The investigated plants of the genus Berberis $L$. can be recommended for the introduction into large-scale and individual gardening in order to expand the range of fruit products and obtain biologically valuable raw materials for the industrial production of functional products.
\end{abstract}

Keywords: Non-traditional fruit crops; Barberries; Water deficiency; Transpiration; Seed productivity; Promising species

\section{Introduction}

The impact of negative environmental factors on the background of arid steppe climate significantly affects all elements of ecosystems, causing soil impoverishment (Savosko, 2011; Savosko et al., 2018), changes in the composition of plant communities (Baranovski et al., 2017; Chytry et al., 2017; Shupranova et al., 2017; Klymenko et al., 2017; Lykholat et al., 2018b, 2018c; Nazarenko \& Lykholat, 2018a; Nazarenko et al., 2018b), changes in the spread of animal organisms and their metabolism (Brygadyrenko, 2015; Andrusevich et al., 2018; Didur et al., 2018; Lykholat et al., 2016a, 2018a, 2019; Marenkov et al., 2019; Pokhylenko et al., 2019), as well as negative effects on the human health (Lykholat et al., 2016b; Pertseva et al., 2012; Yermishev et al., 2017).

In the steppe zone of Ukraine, maintaining the existing plant diversity and expanding its spectrum can be effective if species are introduced from other geographical areas. Particular attention is paid to fruit plants, a significant group of which are non-traditional fruit crops (Khromykh et al., 2018a; 2018b), which are characterized by rapid growth, durability, annual abundant fruiting, high taste and therapeutic and dietary qualities of fruits. In addition, they have decorative, phytomeliorative, honey and medicinal properties (Andola et al., 2010). The introduction of fruit crops enriches the diversity of the floristic composition of regional vegetation and at the same time creates the opportunity to expand the raw material base to meet human nutrition and health needs. To date, more than 400 species of fruit and berry plants have been introduced in different regions of Ukraine (Klimenko et al., 2013; Shcherbyna et al., 2017), but the number of species introduced into industrial steppe zone gardening is insufficient. Plant species and hybrids originating from arid or mountainous habitats and having a high adaptive capacity to the steppe climate, including species of the genera Chaenomeles 
L. and Berberis L., may be promising for the region's introduction (Khromykh et al., 2018a, 2018b). The fruits of these plants have high nutritional value and are a source of physiologically active compounds, which has led to their centuries-old use in traditional medicine, and today puts in a number of important objects of numerical research in order to obtain raw materials for the creation of functional products and medicines. Due to the ability to biosynthesis and the accumulation of components with antioxidant properties, the consumption of fruit plants can prevent the development of many diseases caused by oxidative stress (Ros et al., 2004; Sahan et al., 2012). The anticancer, ant mutagenic and anti-inflammatory effects of plants, as well as the effect on the signaling pathways of carcinogen metabolism, are associated with the antioxidant capacity of phenolic compounds (Hoshyar et al., 2017).

In addition to its decorative and phytomeliorative properties, plants of the genus Berberis $L$. are good honey and medicinal plants, and are also used in folk medicine for the treatment of diseases such as jaundice, rheumatism (Kohno \& Kurdyuk, 2010). The presence of berberine, which is an isoquinoline alkaloid, causes therapeutic effects, including antiviral, antimicrobial, anti-diarrheal, antiinflammatory and anti-carcinogenic effects. Berberine has a positive effect on the treatment of type 2 diabetes through activation of the kinase by adenosine mono phosphates, stimulation of glycolysis, and inhibition of mitochondrial function, which subsequently improves lipid and glucose metabolism. Positive effects of berberine in case of heart failure, cardiac arrhythmia and hypertension have been reported (Huang et al., 2010).

In the steppe zone of Ukraine, the introduction of plants from remote geographical areas, including natural and hybrid species of the genera Berberis L., has been taking place at the Botanical Garden of Oles Honchar Dnipro National University (city of Dnipro) for many years (Figure 1). The study of phenolic compounds content in the fruits of introduced barberry plants revealed the dependence of their accumulation both on the species properties of the plants and on environmental conditions (Khromykh et al., 2018a). Generally, the content of physiologically active substances in fruits and other parts of plants has been shown to be genetically determined and at the same time have a high dependence on the microclimatic and edaphic conditions under which the ontogenetic development of fruit plants occurred. For example, the total content of alkaloids in the stems and roots of different species of the genus Berberis depends on the regions of plant origin (Di et al., 2003). It was shown that in B. asiatica plants in the western Himalayas, the content of berberine was significantly higher in populations that grew at low altitude, and in all populations was higher in roots than in stems. The content of berberine and other biologically active compounds is greatly influenced by the moisture and potassium content of the soil (Andola et al., 2010), which is particularly relevant for the steppe zone of Ukraine, where the climate has continental features and is not equally favorable to all introduced plant species, even within the genus.

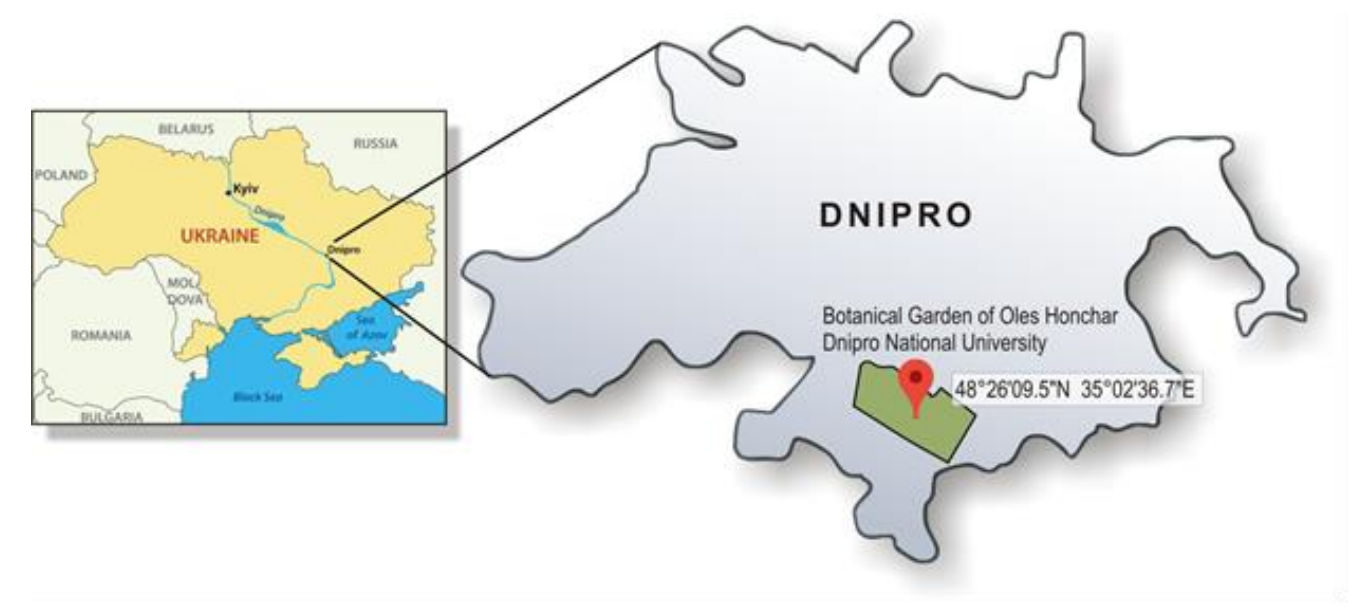

Figure 1. Location of Oles Honchar Dnipro National University Botanical Garden on Dnipro city territory.

The purpose of present study was to identify patterns of influence of the steppe zone difficult climatic conditions on the processes of vegetation and reproduction of the genus Berberis $L$. representatives, introduced from different geographically distant regions. The relevance of the work is due to the need to characterize the level of adaptation of these species to the steppe climate, to evaluate the industrial characteristics of fruits and seeds, and to justify the expediency of wide introduction of species of the genus Berberis $L$. in the climatic conditions of the steppe zone.

\section{Material and Methods}

Samples of plants were collected on the territory of Botanical Garden of Oles Honchar Dnipro National University (DNU) during 2017-2019. Objects of the study were representatives of the genus Berberis $L$. from the collection of the Botanical Garden, most of which were planted 50-60 years ago. During the period of the formation of the collection, 30 species have been introduced, currently accounting for 120 taxa and causing a significant diversity of the modern collection of Berberis L. genus (Table 1 ).

Phenological observations according to (Kohno \& Kurdyuk, 2010) were carried out by a group of representatives of the genus Berberis $L$, originating from different natural habitats: European ( $B$. vulgaris L.), northeast China ( $B$. amurensis Schneid.), Korea ( $B$. koreana Palib.), North America (B. canadensis Mill. as well as $B$. declinata, which is a spontaneous hybrid of $B$. canadensis and $B$. vulgaris). Intensity of transpiration and water deficiency in leaves of introduced fruit plants was carried out in 30-fold repetition (Grigoryuk et al., 2003; Vinnychenko et al., 2014). The experiments were carried out throughout the growing season. The weight of the fruits and seeds of the introduced barberries species was determined by five-fold weighting.

To compare sample averages, the criterion for the significant difference of Tukey's group averages was used (Honestly Significant Difference test or Tukey's HSD test). Tukey's criterion allows for multiple pairwise comparisons of averages. The difference in the mean was found statistically significant with a confidence probability of $P \geq 95 \%$. Tukey's multiple criterion calculation was performed in the Statgraphics Centurion XV Version 15.1.02 computer application software package. 
Table 1. The composition of the Berberis L. species collection in the Botanical Garden of Oles Honchar DNU

\begin{tabular}{ll}
\hline \multicolumn{1}{c}{ Series } & \multicolumn{1}{c}{ Species } \\
Asiaticae (Schneid.) Rehd. & B. lycium Royle. \\
Angulosae (Schneid.) Rehd. & B. tischleri Schneid. \\
Polyanthae (Schneid.) Rehd. & B. polyantha Hemsl. \\
Tinctoriae (Schneid.) Rehd. & B. aristata D.C. \\
& B. macracantha Schrad. \\
Integerrimae (Schneid. ) Rehd. & B. nummularia Bge. \\
Tschonoskyanae (Schneid.) Rehd. & B. heteropoda Schrenk. \\
Sinensis (Schneid.) Rehd. & B. oblonga ( Rgl.) Schneid. \\
Sinensis (Schneid.) Rehd. & B. thunbergii DC. \\
& B. poirettii Schneid. \\
& B. laxiflora Schrad. \\
& B. canadensis Mill. \\
& B. koreana Palib. \\
& B. tibetica Schneid. \\
Vulgares ( Schneid. ) Rehd. & B. vurensis Hupr. \\
& B. vulgaris L. \\
& B. vulgaris var. serrata \\
& B. vulgaris var. sulcata \\
& B. vulgaris var. rotundifolia \\
& B. provincialis (Audib.) Schrad \\
\hline
\end{tabular}

\section{Results and Discussion}

Now the Botanical garden collection includes 18 kinds, 3 hybrids and 5 forms of the genus Berberis $L$. There are most widely presented kinds, a natural habitat of that is China (23\%) Middle Asia (14\%) and Himalayas (14\%). In the collection kinds, that take place from India, Tibet and Siberia are absent.

The results obtained are consistent with the general state of introduction of barberry species, hybrids and ornamental forms in Ukraine. According to the literature, today there are more than 100 introduced barberry plants, among which species predominate, the natural range of which is China (56 species), the Himalayas (14 species) and Central Asia (10 species). Most species of the genus Berberis $L$. have been introduced in Polissia, the Northern Crimea, Transcarpathia, Forest-Steppe, and Steppe (Klimenko et al., 2010; Kohno \& Kurdyuk, 2010). According to the results of our observations, conducted in the late March to early November, it was possible to distinguish two groups by the time of growing season beginning: early (E) during 01.04.-08.04, 25.03-04.04; late (L) during 09.04.-15.04, 05.04-15.04, and three groups by the termination of the growing season: early (E) during 21.09.-30.09, 26.09-07.10; mean (M) during 01.10.-10.10, 08.10.-19.10, and late (L) during 11.10.-22.10, 20.10-01.11. The combination of the selected phenological phases terms yielded six phenological groups: EE, EM, EL, LE, LM, LL (Table 2).

Table 2. Distribution of the genus Berberis L. species into groups depending on the beginning and the end of the main development phases.

\section{Species, varieties,} hybrids
Phenological group

\section{Growing season duration}

B. Iycium Royle.

B. tischleriSchneid

B. polyantha Hemsl.

$B$. aristata DC.

B. macracantha Schrad.

B. nummularia Bge.

B. heteropoda Schrenk.

B. oblonga (Rgl.) Schneid.

B. thunbergii DC.

B. poirettii Schneid.

B. laxiflora Schrad.

B. canadensis Mill.

B. koreana Palib.

B. tibetica Schneid.

B. amurensis Hupr.

$B$. vulgaris $\mathrm{L}$.

B. vulgaris var. atropurpurea

B. vulgaris var. serrata

B. vulgaris var. rotundifolia

B. vulgaris var. sulcata

$B$. provincialis

$\begin{array}{lll}\text { EL } & \text { EM } & \text { LL } \\ \text { EM } & \text { EE } & \text { LL } \\ \text { EM } & \text { EE } & \text { LL } \\ \text { EL } & \text { EM } & \text { LL } \\ \text { EE } & \text { EE } & \text { EE } \\ \text { LL } & \text { LL } & \text { LE } \\ \text { EM } & \text { LL } & \text { LL } \\ \text { EL } & \text { EM } & \text { LL } \\ \text { LL } & \text { LL } & \text { LE } \\ \text { EE } & \text { EE } & \text { EE } \\ \text { EE } & \text { EM } & \text { EE } \\ \text { LL } & \text { EE } & \text { LL } \\ \text { EE } & \text { LE } & \text { EE } \\ \text { EE } & \text { EE } & \text { EE } \\ \text { LL } & \text { EM } & \text { LL } \\ \text { EE } & \text { EE } & \text { EE } \\ \text { LM } & \text { LM } & \text { LL } \\ \text { EM } & \text { EM } & \text { LL } \\ \text { EM } & \text { EM } & \text { LL } \\ \text { EE } & \text { EE } & \text { LL } \\ \text { EE } & \text { EE } & \text { EE }\end{array}$

\section{Growth of shoots}

LL LL

LL EL

LL EL

LL LL

EE EE

LE LE

LL LL

LL LL

LE LE

EE $\quad$ EE

EE EE

LL EE

EE

EE

EL

LL

L

LL LL

LL LL

EE $\quad$ EE

\section{Flowering}

Ripening of fruits

$\begin{array}{ll} & E E \\ & E E \\ & E E \\ & E E \\ & E E \\ & \text { LL } \\ & E E \\ & E E \\ & \text { LE } \\ & E E \\ & E E \\ & \text { LL } \\ & E E \\ & E E \\ \text { LL } \\ \text { EE } \\ \text { EE } \\ \text { EE } \\ \text { EE } \\ \text { LE } \\ \text { EE }\end{array}$

EE
EE
EE
EE
EE
LL
EE
EE
LE
EE
EE
LL
EE
EE
LL
EE
EE
EE
EE
LE
EE

$\begin{array}{lll}\text { EE } & \text { LE } & \text { LL } \\ \text { EE } & \text { EE } & \text { EE } \\ \text { EE } & \text { LL } & \text { LL } \\ \text { EE } & \text { LL } & \text { LL } \\ \text { EE } & \text { EE } & \text { EE } \\ \text { LL } & \text { LL } & \text { LL } \\ \text { EM } & \text { EE } & \text { LE } \\ \text { EE } & \text { LL } & \text { EE } \\ \text { EM } & \text { EE } & \text { LL } \\ \text { EE } & \text { EE } & \text { EE } \\ \text { EL } & \text { LL } & \text { EE } \\ \text { EL } & \text { EE } & \text { EE } \\ \text { EE } & \text { EE } & \text { EE } \\ \text { EE } & \text { EE } & \text { EE } \\ \text { EE } & \text { EE } & \text { EL } \\ \text { EE } & \text { LL } & \text { EE } \\ \text { EE } & \text { EE } & \text { EE } \\ \text { EE } & \text { EE } & \text { EE } \\ \text { EL } & \text { LL } & \text { LL } \\ \text { EM } & \text { EE } & \text { EE } \\ \text { EE } & \text { LL } & \text { EE }\end{array}$


Due to the difference of phenological rhythms, the investigated species of barberry were grouped into several groups. So, introduced plants of the genus Berberis $L$. in the steppe zone have a relatively short growing season, relatively long shoot growth, a short flowering period and a long period of fruit ripening. The analysis of the obtained results indicates the lability of phenological rhythms of the studied plants, which respond to changes in environmental conditions by the onset and end of phenological phases. Adaptation of plants to the influence of the set of environmental factors is largely determined by the ability of the plant organism to withstand water consumption. The stressful condition that occurs in plants at excessive consumption of water leads to changes in the water metabolism of plant organisms. The degree of these indicators variability in adverse conditions of water supply reflects the stability of variability plant organism (Lykholat et al., 1987; Grygoryuk et al., 2014). The reaction of plants to extreme environmental conditions is manifested primarily in changes in the total water content and shape in leaves, as evidenced by such indicators as the intensity of transpiration and the level of water deficiency.

It is known that these indicators may increase or decrease depending on the intensity of environmental factors, first of all, the temperature of the air and the moisture content of the soil (Zaitseva \& Dolhova, 2010; Grygoryuk et al., 2014). The real danger of water imbalance in the plant organism arises due to the high intensity of transpiration during the period of inflow of limited amount of water into the plants, which is most clearly manifested in the conditions of the continental climate of the steppe zone of Ukraine (Lykholat, 1999; Lykholat et al., 2019). If excessive water loss by plants is not renewed in time, there is a gradual dehydration of the plant organism, which leads to the manifestation of signs of water deficiency.

To correctly assess the level of adaptation of introduced Berberis $L$. species to the climatic conditions of the steppe zone, the water balance was studied under arid and moist conditions during the vegetation period of the plants. During the wet period of growing season, plants of the genus Berberis $L$. were characterized by an increased intensity of the transpiration process (Table 3). In the plants leaves of the studied barberry species, the water consumption due to transpiration varied within a rather wide range from $65.5 \mathrm{mg} / \mathrm{g}$ (B. canadensis) to $177.6 \mathrm{mg} / \mathrm{g}$ (B. vulgaris).

Table 3. Transpiration intensity in leaves of the genus Berberis $L$. plants during the wet growing season, $\mathrm{mg} / \mathrm{h}$ per hour.

\begin{tabular}{llll}
\hline \multicolumn{1}{c}{ Species } & \multicolumn{1}{c}{ Average } & $\begin{array}{c}\text { Standard } \\
\text { Deviation }\end{array}$ & $\begin{array}{c}\text { Variation } \\
\text { coefficient, \% }\end{array}$ \\
B. declinata & 123.61 & 0.1626 & 0.13 \\
B. amurensis & 136.61 & 0.2178 & 0.16 \\
B. koreana & 132.55 & 0.3799 & 0.29 \\
B. vulgaris & 177.64 & 0.2151 & 0.12 \\
B. canadensis & 65.48 & 0.2601 & 0.40 \\
\hline
\end{tabular}

In our study, it was found that the level of water deficit in leaves of introduced plants of the genus Berberis $L$. varied from $14.6 \%$ (B. amurensis) to $16.2 \%$ (B. canadensis) under drought conditions (Table 4).

Table 4. Water deficiency indicators in leaves of the genus Berberis $L$. plants during the dry season of vegetation, $\%$.

\begin{tabular}{lccc}
\hline \multicolumn{1}{c}{ Species } & Average & $\begin{array}{c}\text { Standard } \\
\text { Deviation }\end{array}$ & $\begin{array}{c}\text { Variation } \\
\text { coefficient, \% }\end{array}$ \\
B. declinata & 15.33 & 0.1429 & 0.93 \\
B. amurensis & 14.62 & 0.0900 & 0.62 \\
B. koreana & 16.14 & 0.1266 & 0.79 \\
B. vulgaris & 14.85 & 0.1277 & 0.86 \\
B. canadensis & 16.16 & 0.1365 & 0.84 \\
\hline
\end{tabular}

The comparative analysis revealed significant differences (99.9\%) of water deficit indicators during the dry season of vegetation for most of the species studied. The exceptions to the general pattern were the comparative pair of species $B$. amurensis and $B$. vulgaris (less than 95\%) and the pair of species B. declinata and B. vulgaris, for which differences were found at $95 \%$ confidence level. During the growing season under high humidity conditions, the water deficit in leaves of plants of the genus Berberis $L$. varied from $8.1 \%$ in $B$. declinata to $15.2 \%$ in $B$. vulgaris leaves (Table 5 ).

Table 5. Water deficiency indicators in leaves of the genus Berberis $L$. plants during the wet season of vegetation, \%.

\begin{tabular}{llll}
\hline Species & Average & $\begin{array}{l}\text { Standard } \\
\text { Deviation }\end{array}$ & $\begin{array}{l}\text { Variation } \\
\text { coefficient, \% }\end{array}$ \\
B. declinata & 8.14 & 0.0854 & 1.05 \\
B. amurensis & 8.81 & 0.0954 & 1.08 \\
B. koreana & 8.78 & 0.0917 & 1.04 \\
B. vulgaris & 15.15 & 0.1735 & 1.14 \\
B. canadensis & 10.16 & 0.0551 & 0.54 \\
\hline
\end{tabular}

Statistically significant differences (99.9\%) of water deficit levels during the wet growing season were found for all species studied within the genus Berberis L., except for the comparable pair of B. declinata and B. koreana species (less than $95 \%$ ). Increased water deficiency in plants is the cause of their reduced fertility and poor fruit quality. The variability of fruiting and seed productivity of plant species is based on the characteristics of the genotype, which may differ in different environmental conditions and cause phenotypic variation. Genotypic factors cause specific differences in the reproductive capacity of different plant species. Phenotypic differences are determined by meteorological conditions during the growing season, causing differences in fruiting levels and seed productivity in different years. The results of comparative analysis of morphometric indicators of fruits indicate the variability of fruiting of introduced plants of the genus Berberis $L$. in the steppe climate (Table 6). 
Table 6. Morphometric characteristics of the fruits of genus Berberis L. plants, average for three years.

\begin{tabular}{llll}
\hline \multicolumn{1}{c}{ Species } & Diameter of fruits, $\mathbf{~ m m}$ & Length of fruits, $\mathbf{~ m m}$ & Weight of $\mathbf{1 0 0}$ fruits, $\mathbf{g}$ \\
B. declinata & $5.2 \pm 0.15$ & $8.5 \pm 0.20$ & $16.3 \pm 0.12$ \\
B. canadensis & $4.1 \pm 0.10$ & $9.1 \pm 0.15$ & $15.2 \pm 0.11$ \\
B. koreana & $5.1 \pm 0.12$ & $9.2 \pm 0.11$ & $15.6 \pm 0.15$ \\
B. amurensis & $4.2 \pm 0.10$ & $11.1 \pm 0.10$ & $15.8 \pm 0.12$ \\
B. vulgaris & $5,8 \pm 0.12$ & $9.2 \pm 0.11$ & $12.5 \pm 0.03$ \\
\hline
\end{tabular}

In the steppe climate, fruit length of the barberry plants varied from $8.5 \pm 0.20 \mathrm{~mm}$ ( $B$. declinata) to $11.1 \pm 0.10 \mathrm{~mm}$ ( $B$. amurensis), fruit diameter varied from $4.1 \pm 0.10 \mathrm{~mm}$ ( $B$. canadensis) to $5.2 \pm 0.15 \mathrm{~mm}$ ( $B$. declinata). The largest fruits were observed in $B$. declinata plants, the largest fruits were observed in species $B$. vulgaris. The weight of 100 fruits ranged from $12.5 \pm$ $0.03 \mathrm{~g}$ (B. vulgaris) to $16.3 \pm 0.12 \mathrm{~g}$ ( $B$. declinata). In our study, the quantitative characteristics of the seeds testified to the considerable variability of seed productivity of introduced plants of the genus Berberis $L$. in the conditions of the steppe climate (Table 7).

Table 7. Characteristics of seeds of the genus Berberis $L$. introduced plants, average for three years.

\begin{tabular}{llcl}
\hline \multicolumn{1}{c}{ Species } & Seed size, $\mathbf{~ m m}$ & Weight of 1000 seeds, \\
B. declinata & Wength & Width & g \\
B. canadensis & $5.2 \pm 0.05$ & $1.9 \pm 0.01$ & $7.6 \pm 0.31$ \\
B. koreana & $4.5 \pm 0.11$ & $1.8 \pm 0.04$ & $11.0 \pm 0.42$ \\
B. amurensis & $4.8 \pm 0.15$ & $2.1 \pm 0.02$ & $11.5 \pm 0.41$ \\
B. vulgaris & $5.2 \pm 0.13$ & $2.0 \pm 0.03$ & $9.4 \pm 0.39$ \\
\hline
\end{tabular}

Seed length varied from $4.5 \mathrm{~mm}$ (B. canadensis) to $5.2 \mathrm{~mm}$ (B. declinata, B. amurensis), width varied from $1.8 \mathrm{~mm}$ (B. amurensis, B. vulgaris) to $2.1 \mathrm{~mm}$ (B. koreana). The weight of 1000 seeds, depending on their size and occupancy, averaged $10.16 \mathrm{~g}$. The highest mass of 1000 seeds was observed in the rape fruit of $B$. koreana plants. In order to enrich the range of ornamental and fruit plants in the steppe zone of Ukraine, it is advisable to introduce new crops into the production and to expand the species diversity of the Berberis $L$. genus. The process of reproduction of barberry depends on many factors: the ability of the plant to generate generative organs, hereditary information due to age-related changes in the body, interaction with the environment.

\section{Conclusion}

The response of introduced plants of the genus Berberis $L$. to the level of moisture in the steppe region confirmed the universal mechanism of adaptation of plants to arid conditions. A moderate water deficit in arid conditions was noted for all the species of barberry studied, indicating their high resistance to the climatic conditions of the region. Thus, all investigated introduced representatives of the genus Berberis $L$. are promising for use in the greening system in the steppe zone of Ukraine and as fruit plants for functional nutrition of the population and raw materials for the food industry.

\section{References}

Andola, H. C., Gaira, K. S., Rawal, R. S., Rawat, M. S., \& Bhatt, I. D. (2010). Habitat-dependent variations in berberine content of Berberis asiatica Roxb. ex. DC. in Kumaon, Western Himalaya. Chemistry \& Biodiversity, 7(2), 415-420. doi: 10.1002/cbdv.200900041

Andrusevich, K. V., Nazarenko, M. M., Lykholat, T. Yu., \& Grigoryuk, I. P. (2018). Effect of traditional agriculture technology on communities of soil invertebrates. Ukrainian journal of Ecology, 8(1), 33-40. doi: 10.15421/2017_184

Baranovski, B., Khromykh, N., Karmyzova, L., Ivanko, \& Lykholat, Y. (2016). Analysis of the alien flora of Dnipropetrovsk Province. Biological Bulletin of Bogdan Chmelnitskiy Melitopol State Pedagogical University, 6 (3), 419-429. doi: http://dx.doi.org/10.15421/2016113/

Brygadyrenko, V. V. (2015). Community structure of litter invertebrates of forest belt ecosystems in the Ukrainian Steppe Zone. International Journal of Environmental Research, 9 (4), 1183-1192. doi: 10.22059/IJER.2015.1008

Chytry, M., Horsák, M., Syrovátka, V., Danihelka, J., Ermakov, N., German, D., Hájek, M., Hájek, O., Hájková, P., Horsáková, V., Kocí, M., Kubesová, S., Lustyk, P., Nekola, J., Preislerová, Z., Reslh, P., \& Valachovic, M. (2017). Refugial ecosystems in central Asia as indicators of biodiversity change during the Pleistocene-Holocene transition. Ecological Indicators, 76, $357-367$.

Di, D. L., Liu, Y. W., Ma, Z. G., \& Jiang, S. X. (2003). Determination of four alkaloids in Berberis plants by HPLC. Zhongguo Zhong Yao Za Zhi, 28 (12), 1132-1134.

Didur, O., Kulbachko, Y., Maltsev, Y. (2018). Impact of tropho-metabolic activity of earthworms (Lumbricidae) on distribution of soil algae within Acer platanoides L. plantation in recultivated territories of Western Donbass (Ukraine). Ukrainian Journal of Ecology, 8 (2), 18-23. doi: http://dx.doi.org/10.15421/2018_304/

Grigoryuk, I. A., Tkachev, V. I., Savinskiy, S. V., \& Musienko, N. N. (2003). Sovremennye metody issledovaniya i otsenki zasukho- i zharoustoychivosti rasteniy [Modern methods of investigation and assessment of drought and heat resistance of plants]. Naukovyy svit, Kyiv. (In Ukrainian).

Hoshyar, R., Mahboob, Z., \& Zarban, A. (2016). The antioxidant and chemical properties of Berberis vulgaris and its cytotoxic effect on human breast carcinoma cells. Cytotechnology, 68, 1207-1213. https://doi.org/10.1007/s10616-015-9880-y/

Hryhoriuk, I. P., Yavorovskyi, P. P., \& Lykholat, Yu. V. (2014) Tekhnolohii vyroshchuvannia i biorehuliatsiia stiikosti hazonnykh roslyn u miskomu urbanizovanomu seredovyshchi [Technology of cultivation and bioregulation of the stable of lawn plants in city urbanized environment]. Kyiv. Показаны National University of Life and Environmental Science Institue of Ukraine (in Ukrainian). 
Huang, W. Y., Cai, Y. Z., \& Zhang, Y. (2010). Natural phenolic compounds-from medicinal herbs and dietary plants: potential use for cancer prevention. Nutrition and Cancer, 62 (1), 1-20. doi: 10.1080/01635580903191585

Klymenko, A., Kovalenko, I., Lykholat, Yu., Khromykh, N., Didur, O., \& Alekseeva, A. (2017). Intehralna otsinka stanu populiatsii ridkisnykh vydiv roslyn [The integral assessment of the rare plant populations]. Ukrainian Journal of Ecology, 7(2), 201-209. doi: http://dx.doi.org/10.15421/2017_37

Khromykh, N. O., Lykholat, Y. V., Kovalenko, I. M., Kabar, A. M., Didur, O. O., \& Nedzvetska M. I. (2018a). Variability of the antioxidant properties of Berberis fruits depending on the plant species and conditions of habitat. Regulatory Mechanisms in Biosystems, 9 (1), 56-61. doi: 10.15421/021807.

Khromykh, N., Lykholat, Y., Shupranova, L., Kabar, A., Didur, O., Lykholat, T., \& Kulbachko, Y. (2018b). Interspecific differences of antioxidant ability of introduced Chaenomeles species with respect to adaptation to the steppe zone conditions. Biosystems Diversity, 26 (2), 132-138. https://doi.org/10.15421/011821

Klymenko, S., Brinza, J., \& Grigorieva, O. (2013). Non-traditional fruits and berry plants in the Register of sorts of plants of Ukraine. Czlovek - Natura - Kultura: Materials of Conference by Professor J. Piorecki 80 year. Rzeszow, 69-74.

Kohno, N. A., \& Kurdyuk, A. M. (2010). Teoreticheskie osnovyi i opyit introduktsii drevesnyih rasteniy v Ukraine. [Theoretical bases and experience of introduction of arboreal plants are in Ukraine]. Ichnya, PP Format. (in Ukrainian).

Kotsariev, O. S., Antoniuk, S. V., \& Lykholat, O. A. (2001). Strukturno-funktisonal'ni osoblyvosti aerohematychnoho bar'iera lehen' za umov inhaliatsiinoï diï nyz'kykh kontsentratsii soli svyntsiu. [Structural-functional characteristics of the air-blood barrier of lungs upon inhalation of low concentrations of lead salt]. Fiziolohichnyi zhurnal (Kiev, Ukraine), 47 (4), 36-41.

Lykholat, O. A., Grigoryuk I. P., \& Lykholat T. Y. (2016a). Metabolic effects of alimentary estrogen in different age animals. Annals of Agrarian Science, 14 (4), 335-339. https://doi.org/10.1016/j.aasci.2016.09.012

Lykholat, T. Y., Marenkov, O. M., Yashchenko, K. V., Shaldyna, E. S., \& Lykholat, O. A. (2018a). Vplyv syntetychnykh estrogeniv u produktakh kharchuvannya na sistemu detoksykatsii tvaryn riznogo viku [Influence of synthetic ethrogenes in food products on the detoxication system of animal animals of different age]. Scientific Reports of NULES of Ukraine, 2 (72). (in Ukrainian). http://journals.nubip.edu.ua/index.php/Dopovidi/article/view/10635

Lykholat, T. Yu., Lykholat, O. A., Marenkov, O. M., Kulbachko, Yu. L., Kovalenko, I. M., \& Didur, O. O. (2019). Xeneostrogenes influence on cholinergic regulation in female rats of different age. Ukrainian Journal of Ecology, 9(1), $240-243$.

Lykholat, T., Lykholat, O., \& Antonyuk, S. (2016b). Immunohistochemical and biochemical analysis of mammary gland tumours of different age patients. Cytology and Genetics, 50(1), 32-41. https://doi.org/10.3103/S0095452716010072/

Lykholat, Y. V., Dolgova, L. G., \& Ilkun, G. M. (1987). Izmenenie vodnogo obmena rasteniy pri zagryaznenii atmosfernogo vozduha organicheskimi zagryaznitelyami [Changes in water exchange of plants under atmospheric air-pollution with organic-solvents]. Fiziologiya I Biokhimiya Kulturnykh Rastenii, 19 (1), 77-81. (in Russian).

Lykholat, Y., Khromykh, N., Didur, O., Alexeyeva, A., Lykholat, T., \& Davydov, V. (2018b). Modeling the invasiveness of Ulmus pumila in urban ecosystems under climate change. Regulatory Mechanisms in Biosystems, 9(2), 161-166. doi: 10.15421/021824

Lykholat, Yu. V. (1999). Bioindykatsiia dovkillia za dopomohoiu hazonnykh trav [Bioindication of the environment with lawn grasses]. Materials of the 2nd International. conf.: Science \& Education'99. Kyiv-Dnipropetrovsk, vol. 3, 25-26. (in Ukrainian).

Lykholat, Yu. V., Khromykh, N. O., Pirko, Ya. V., Alexeyeva, A. A., Pastukhova, N. L., \& Blume, Ya. B. (2018c). Epicuticular wax composition of leaves of Tilia L. trees as a marker of adaptation to the climatic conditions of the steppe Dnieper. Cytology and Genetics, 52 (5), 323-330. DOI: 10.3103/S0095452718050067

Marenkov, O., Lykholat, T., Lykholat, O., \& Petrovsky, O. (2019). Level of Edcs in Procambarus virginalis organism at developing stages as potential hazard for water biota and aquatic culture consumers. Third International Conference "Smart Bio" (02-04 May 2019). Kaunas, Lithuania.

Mytsyk, L. P., \& Lykholat, Yu. V. (2000). Riven' akumulyatsii vajkyh metaliv u roslynah Poa angustifolia L. u shtuchnyh biogeotsenozah [A level of accumulation of heavy metals is in the plants of Poa of angustifolia L. in artificial geobiocenosiss]. Issues of steppe forestry and forest reclamation of soils, 4, 25-28. (in Ukrainian).

Nazarenko, M. M., \& Lykholat, Y. V. (2018a). Influence of relief conditions on plant growth and development. Bulletin of the University of Dnepropetrovsk. Geology, geography, 26 (1), 143-149. doi: 10.15421/111815

Nazarenko, M., Lykholat, Y., Grigoryuk, I., \& Khromykh, N. (2018b). Optimal doses and concentrations of mutagens for winter wheat breeding purposes. Part I. Grain productivity. Journal of Central European Agriculture, 19 (1), 194-205. DOI: 10.5513/JCEA01/19.1.2037

Pertseva, T. A., Lykholat, E. A., \& Gurzhiy, E. V. (2007). Ocenka sostoyaniya mukociliarnogo klirensa u pacientov s hronicheskim obstruktivnym zabolevaniem lyogkih [The evaluation of mucociliary clearance in patients with chronic obstructive pulmonary disease]. Ukrainian Pulmonology Journal, 3, 16-18. (in Ukrainian).

Pertseva, T. A., Lykholat, E. A., \& Gurzhiy, E. V. (2008). Vliyanie tiotropiya bromida na sostoyanie mukociliarnogo klirensa u bol'nyh hronicheskim obstruktivnym zabolevaniem legkih. [The influence of tiotropium bromide on mucociliary clearance's condition in patients with chronic obstructive pulmonary disease]. Ukrainian Pulmonology Journal, 1, 13-15. (in Ukrainian).

Pertseva, T., Lykholat, O., \& Gurzhiy, O. (2012). Influence of tiotropium bromide (TB) and carbocysteine (C) on mucociliary clearance (MCC) in patients with COPD. European Respiratory Journal, 40 (56), 3466.

Pokhylenko, A., Lykholat, O., Didur, O., Kulbachko, Y., \& Lykholat, T. (2019). Morphological variability of Rossiulus kessleri (Diplopoda, Julida) from different biotopes within Steppe Zone of Ukraine. Ukrainian Journal of Ecology, 9 (1), $176-182$.

Ros, J. M., Laencina, J., Hellín, P., Jordán, M. J., Vila, R., Rumpunen, K. (2004). Characterization of juice in fruits of different Chaenomeles species. LWT-Food Science and Technology, 37 (3), 301-307. doi: 10.1016/j.Iwt.2003.09.005

Sahan, Y., Cansev, A., Celik, A., \& Cinar, A. (2012). Determination of various chemical properties, total phenolic content, antioxidant capacity and organic acids in Laurocerasus officinalis fruits. Acta Horticulturae, 939, 359-366.

Savosko, V. M. (2011). Melioraciya ta fitorekultyvaciya zemel [Land melioration and phyreclamation]. Dionis, Kryvyj Rih. (in Ukrainian).

Savosko, V., Lykholat, Yu., Domshyna, K., \& Lykholat, T. (2018). Ekolohichna ta heolohichna zumovlenist poshyrennia derev i chaharnykiv na devastovanykh zemliakh Kryvorizhzhia [Ecological and geological determination of trees and shrubs' dispersal on the devastated lands at Kryvorizhya]. Journal of Geology, Geography and Geoecology, 27(1), 116-130. (in Ukrainian). doi: $10.15421 / 111837$ 
Shcherbyna, R. O., Danilchenko, D. M., Parchenko, V. V., Panasenko, O. I., Knysh, E. H., Khromykh, N. O., \& Lykholat, Y. V. (2017). Studying Of 2-((5-R-4-R1-4H-1,2,4-Triazole-3-YI)Thio)Acetic Acid Salts Influence On Growth And Progress Of Blackberries (KIOWA Variety) Propagules. Research Journal of Pharmaceutical, Biological and Chemical Science, 8, 975-979.

Shupranova, L. V., Lykholat, Y. V., Khromikh, N. O., Grytzaj, Z. V., Alexeyeva, A. A., \& Bilchuk, V. S. (2017). Reaction of photosynthetic apparatus of a representative of extrazonal steppe plants Quercus robur to air pollution by motor vehicle emissions. Biosystems Diversity, 25 (4), 268-273. doi: https://doi.org/10.15421/011741

Vinnychenko, O. M., Bil'chuk, V. S., Lykholat, Yu. V., Rossyhina-Galycha, H. S., \& Shupranova, L. V. (2014). Speczpraktykum z fiziologiyi ta biohimiyi roslyn [Special practice on physiology and biochemistry of plants]. FOP Serednyak T. K., Dnipropetrovsk. (in Ukrainian).

Yermishev, O., Lykholat, O., \& Lykholat, O. (2017). Effect of alimentary synthetic estrogen on cell compensatory mechanisms in rats of different ages. Biologija, 63 (2), 152-159.

Zaitseva, I. O., \& Dolhova, L. H. (2010). Fizioloho-biokhimichni osnovy introduktsii derevnykh roslyn u stepovomu Prydniprovi [Physiological and biochemical foundations of the introduction of woody plants in the Steppe Dnieper]., Dnipropetrovsk. Dnipropetrovsk National Univerity Press (in Ukrainian).

\section{Citation:}

Lykholat, Y.V., Khromykh, N.O., Lykholat, T.Y., Bobrova, O.M., Didur, O.O. et al. (2019). Introduction success of less common species from the genus Berberis L. Ukrainian Journal of Ecology, 9(4), 634-640.

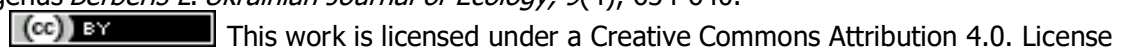

